\title{
Recuerdo de Don Pedro
}

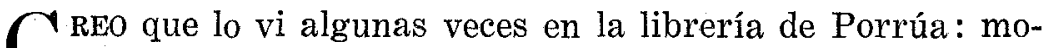
reno, de otra manera que sus compañeros mexicanos, con el aire del trópico, con su sol en la piel, parecido a los míos de la costa del Golfo, y con algo más, diferente, entre tabasqueño y antillano $\mathrm{y}$, si no me equivoco, con gran sombrero de fieltro negro. ¿Lo vi entonces, o lo imaginé después bajo la sugestión de alguna fotografía?...

Poco lo leí en México, es la verdad, pero mucho en París, donde me dediqué a buscar lo hispano en el mundo y, sobre todo, lo hispanoamericano en lo hispánico. Y no sólo lo leí, sino lo estudié, en Bédarrides de Vaucluse, en la Provenza, en la casa de Gabriela Mistral, donde pasé una buena temporada del año de 1929. "Busque su América, muchacho", me decía Gabriela, siempre. Y a menudo: "en Pedro, en Alfonso, en Vasconcelos, en Caso la encontrará". Los admiraba mucho, y a Henríquez Ureña, a Reyes y a otros los recordaba con su nombre de pila. Y yo hacía lo mismo, un poco por su influencia $\mathrm{y}$ un mucho por desacato juvenil, por un vano e inconfesado intento de hombrearme con los grandes de América. $Y$, en el caso de Alfonso, porque el casi tuteo de Gabriela era lluvia sobre mojado: mi padre, desde mi infanca así llamaba a los hijos de don Bernardo. A Vasconcelos nunca le dije Pepe porque Gabriela no se lo decía y, quizá más, porque era el caudillo político de mis compañeros, y algo el mío, a la distancia y demasiado discutido en mis adentros, para justa furia y continua polémica epistolar con mis íntimos amigos Andrés Pedrero y Herminio Ahumada, que en ese momento peleaban cívica y heróicamente junto con él; 
y menos a Caso le llamé Antonio, en parte porque Gabriela no me enseñó a hacerlo, y sobre todo, porque había sido mi maestro. Lo cierto es que en Francia vivía yo en el seno de la alta familia en cuya cima veíamos al casi abuelo de todos, don Justo Sierra, y en la que no era menos mexicana la rica rama, copiosa de frutos, del sabio y buen dominicano.

Pero, de carne y hueso, de voz y plática, no vine a conocerlo sino en 1941, quizá en febrero, aquí en Nueva York. Don Federico de Onís lo invitó a asistir a la sesión de apertura del Instituto Hispánico de la Universidad de Columbia, y asombrado vi su juventud extraordinaria, la piel tersa, el bigote y el pelo negrísimos: yo sabía su edad porque la de la fama es pública. Días después don Tomás Navarro Tomás lo llevó a nuestro apartamento de la calle 123 y la Avenida Amsterdam, donde saboreó y elogió la merienda mexicana de mi esposa, y en seguida oyó los discos que fueron el principal motivo de la visita. Eran aquéllos con los que el periodista español Bonifacio Fernández Aldana quiso iniciar ese archivo de la palabra hispanoamericana que tanta falta sigue haciendo, que tanto pesará mañana que no se haya hecho todavía. Muy bueno era el que recogía la de don Mariano Azuela en aquel pasaje de Demetrio Macías: "Yo soy de Limón, muy cerca de Moyahua, del puro cañón de Juchipila ... Tenía mi casa ... es decir, que nada me falta ... Pero uno es lebroncito de por sí, y un día sale la daga, y la pistola, y vámonos a recorrer la sierra mientras se les olvida el difuntito ...". Cito, a propósito, de memoria, sin ir a las páginas del libro. Don Pedro dijo:

-No sólo es Azuela el que habla: Es la voz del campo de México. Eso lo oyó de alguien, palabra por palabra. Se oye, se siente... Póngalo otra vez. Es México.

$\mathrm{Y}$ varias veces oyó la cadencia que, si no me equivoco, se le había pegado de su estancia en mi patria, de la diaria añoranza y de la esposa mexicana.

Oímos luego a Martín Luis Guzmán en un magnífico elogio de don Francisco I. Madero. "La misma voz metálica, la misma dicción clarísima, la misma inteligencia lúcida", dijo don Pedro. 
Siguió un trozo de Bolivarismo y monroísmo de don José Vasconcelos: parece.

-No, no lo reconozco... ¿Es la voz de Pepe? No lo

Don Tomás hizo entonces recuerdos de su archivo de la palabra del Centro de Estudios Históricos, y hablamos de los defectos de fabricación de los discos de ayer y de entonces, de la alteración de la voz humana al ser grabada, del aspecto técnico que los dos conocíamos muy bien. $\mathrm{Y}$ seguí con la Visión de Anáhuac de Alfonso Reyes:

-No, tampoco es él...

Pero oyó un rato más, y con la voz alterada y los ojos casi llorosos, dijo don Pedro:

-No, me equivocaba. Sí es él, el mismo de siempre.

Recordó los tiempos de la juventud, en una conversación que se empeñaba en no caer en el sentimiento, y el profesor que nunca faltaba en él nos dio detalles precisos, fechas exactas, significativas anécdotas.

De la rememoración mexicana pasamos a la española, y don Tomás nos dio mucho de lo que ocurrió en el Madrid donde Alfonso continuó su brillante camino. $Y$ luego pasamos a los escritores de nueva hornada: recuerdo que habia un precioso disco de Xavier Villaurrutia, y creo - no estoy seguroque otros de Carlos Pellicer, de Jaime Torres Bodet, de José Gorostiza. Habló don Pedro de todos ellos, con tanto conocimiento como estimación.

Semanas después volvió de Boston don Pedro para darnos una conferencia sobre "Poesía pura y poesía social en la América española". Estaba entonces en la Universidad de Harvard, invitado por la fundación Charles Eliot Norton. Fue -nos dice el archivo del Instituto Hispánico- el 24 de marzo de 1941. Yo lo presenté al público, y él solo dijo:

- Ojalá fuera verdad todo lo que ha dicho; pero no lo es. Habla generosamente porque es joven y, quizá más, porque es mexicano.

No volví a verlo. De Buenos Aires me acusó recibo de mi libro sobre Martí, en 1945, y me dijo alguna cosa, ésa sí, generosa. Me pedía datos para incorporarme a no sé qué índice y, por no sé qué absurdo descuido, nunca se los envié. 
Un día supe su repentina muerte. En mi clase de literatura hispanoamericana mis alumnos y yo le hicimos un homenaje; y el Instituto Hispánico, con la palabra de Onís y Navarro Tomás, otro muy hondo.

No dejó de llegarnos su sabiduría y su generosidad, a través de sus libros, de sus amigos, de sus discípulos. Uno tras otro vinieron éstos, cuando el peronismo. Pocos de los que no recibieron su lección valdrán tanto como los que tuvieron ese privilegio. De ese modo se dividen los que escriben y enseñan entre los que si, y los que no. No fue el único maestro, claro, y hay otras cimas; pero su altura intelectual y moral no fácilmente se sobrepasa. Talento, método, sabiduría, y bondad y llaneza no andan a menudo juntos.

Con la admiración vieja, sintiéndolo tan nuestro por América y por México, escribimos hoy sobre él lo único que podemos escribir, y es esta rememoración tan insignificante como devota.

ANDRÉS IDUARTE.

Columbia University, Hispanic Institute, N. York. 